\title{
PEMBUATAN BIODIESEL DARI MIKROALGA CHLORELLA $S p$ \\ MELALUI DUA TAHAP REAKSI IN-SITU
}

\author{
Shintawati Dyah P
}

\begin{abstract}
Abstrak
Biodiesel merupakan bahan bakar alternatif minyak diesel yang sedang dikembangkan di Indonesia. Kebutuhan biodiesel saat ini sebagian dipenuhi dari Jatropa dan tanaman nabati lainnya dalam jumlah kecil. Biodiesel dari tanaman tersebut belum mencukupi, untuk itu dikembangkan biodiesel dari mikroalga Chlorella Sp. Penelitian ini bertujuan untuk mengkaji sifat fisik dan kimia biodiesel yang diperoleh dari mikroalga Chlorella Sp dan membandingkan dengan minyak solar dari minyak bumi (SNI). Biodiesel diproduksi dengan reaksi dua tahap secara in-situ, dimana proses ekstraksi dan esterifikasi dilakukan secara bersama dalam satu reaktor. Esterifikasi dilakukan dalam perbandingan mol reaktan yang berbeda $(1: 20 ; 1: 25 ; 1: 30 ; 1: 35$ dan 1:40), dengan variasi berat katalis $\mathrm{KOH}(0,5$ $\%-b, 1 \%-b, 1,5 \%-b$ dan $2 \%-b$ ) pada suhu $60{ }^{\circ} \mathrm{C}$. Biodiesel yang dihasilkan dilakukan uji massa jenis, viskositas, angka asam, angka setana dan terbentuknya FAME (biodiesel) dengan analisa GCMS. Hasil penelitian menunjukkan sifat fisik dan kimia sudah memenuhi standart biodiesel (SNI), dari hasil penelitian yang diperoleh menunjukkan konsentrasi katalis dan perbandingan reaktan berpengaruh terhadap konversi. Pada esterifikasi menggunakan variasi perbandingan mol reaktan konversi yang tinggi pada perbandingan 1:4 sebesar 36,34. Analisa GC-MS terhadap biodiesel yang diperoleh menunjukkan terbentuknya FAME, dengan senyawa utamanya methil ester Methil palmitate sebesar 30,24\%.
\end{abstract}

Kata kunci : Chlorella Sp, esterifikasi, biodiesel

\section{PENDAHULUAN}

Minyak bumi diperkirakan akan habis dalam 25 tahun mendatang (Suhada, 2006). Pengembangan biodiesel sebagai bahan bakar terbarukan berbasis minyak nabati merupakan suatu langkah yang tepat untuk mengatasi masalah bahan bakar. Biodisel adalah bahan bakar yang ramah lingkungan dan mempunyai keunggulan dibanding bahan bakar minyak diesel yaitu bersifat terbarukan, biodegradable, tidak mengandung sulfur, dan mempunyai kekentalan lebih tinggi sehingga membantu memperpanjang umur mesin disel. Biodisel mempunyai angka setana dan flash point yang tinggi $\left(>130^{\circ} \mathrm{C}\right)$ (Knothe dkk, 2006).

Kebutuhan biodiesel saat ini sebagian dipenuhi dari Jatropa dan tanaman nabati lainnya dalam jumlah kecil. Kebutuhan biodiesel dari tanaman tersebut belum mencukupi, untuk itu dikembangkan biodiesel dari mikroalga Chlorella Sp.

Mikroalga merupakan mikroorganisme fotosintesis yang 
berpotensi digunakan untuk menjadi sumber bahan baku biodiesel (Chisty, 2007). Salah satu mikroalga yang mudah didapatkan dan dikembangkan di Indonesia adalah Chlorella.

Menurut Vashista (1979), Chlorella termasuk dalam filum Chlorophyta, kelas Chlorophyceae, Ordo Chloroccocales, Famili Chlorelllaceae, Genus Chlorella, dan Spesies Chlorella $s p$.

Biodiesel yang diperoleh dari mikroalga Nannochloropsis sp, sudah memenuhi syarat viskositas dan density dalam batasan standar Dirjen Migas (Riza, 2009). Sedangkan penelitian yang dilakukan oleh Sri Hartini pada tahun 2010 dengan mengekstraksi mikroalga Scenedesmus dengan metode fluida super kritikal, memperoleh biodiesel sebesar $60 \%$.

Pada reaksi dua tahap In-situ, proses ekstraksi minyak dan reaksi esterifikasi dilaksanakan secara simultan sehingga tidak menggunakan tahap ekstraksi.

Penelitian ini bertujuan untuk mengkaji sifat fisik dan kimia biodiesel yang diperoleh dari mikroalga Chlorella $S p$ dan membandingkan dengan minyak solar dari minyak bumi (SNI).

\section{BAHAN DAN METODA \\ Bahan dan peralatan \\ Bahan}

Mikroalga chlorella kering, metanol, $\mathrm{KOH}$, aquadest

\section{Peralatan}

Pendingin balik, kompor listrik, labu leher tiga, klem, statif, magnetic stirer, corong pisah, motor pengaduk, beker gelas 250 $\mathrm{ml}$, Erlenmeyer $250 \mathrm{ml}$, timbangan elektrik, pipet $25 \mathrm{ml}$, termostat, labu takar, corong, oven, buret, penyangga, GC-MS.

\section{Metoda}

Biodiesel dibuat dengan proses reaksi dua tahap in-situ dimana proses esterifikasi dengan mereaksikan 40 gram Chlorella sp dengan larutan methanol dalam labu leher dua yang dilengkapi termostat pada suhu $50{ }^{0} \mathrm{C}$ dengan pengadukan konstan menggunakan magnetic stirer selama 30 menit. Kemudian proses dilanjutkan dengan transesterifikasi in-situ. Campuran hasil reaksi didinginkan selama 10 menit untuk menghentikan reaksi. Kemudian hasil reaksi dipisahkan untuk memisahkan antara endapan (chlorella Sp) dan FAME. FAME kemudian diekstraksi menggunakan $50 \mathrm{~mL}$ n-hexane. Akan terbentuk gliserol (lapisan bawah) dan FAME (lapisan atas). Fase FAME ini dicuci dengan air $\left(\mathrm{T}=50 \quad{ }^{\circ} \mathrm{C}\right)$ sebanyak 3x50 mL untuk mengambil gliserol yang masih terikut dalam FAME. Mengambil FAME (lapisan atas) sebagai hasil, lalu mendestilasi FAME tersebut untuk memisahkan FAME dari solvent (heksan) . 
Memasukkan dalam oven pada suhu $80^{\circ} \mathrm{C}$ untuk menghilangkan sisa solvent dan air . Kemudian biodiesel yang diperoleh dianalisis.

\section{Hasil dan pembahasan}

\section{Analisa biodiesel dengan GC-MS}

Analisa ini dilakukan untuk mengetahui terbentuknya metil ester. Analisa dengan GC-MS dipakai untuk mengetahui jenis senyawa yang terkandung di dalam metil ester dari chlorella sp. Hasil analisa GC-MS ditunjukkan pada Gambar 1.

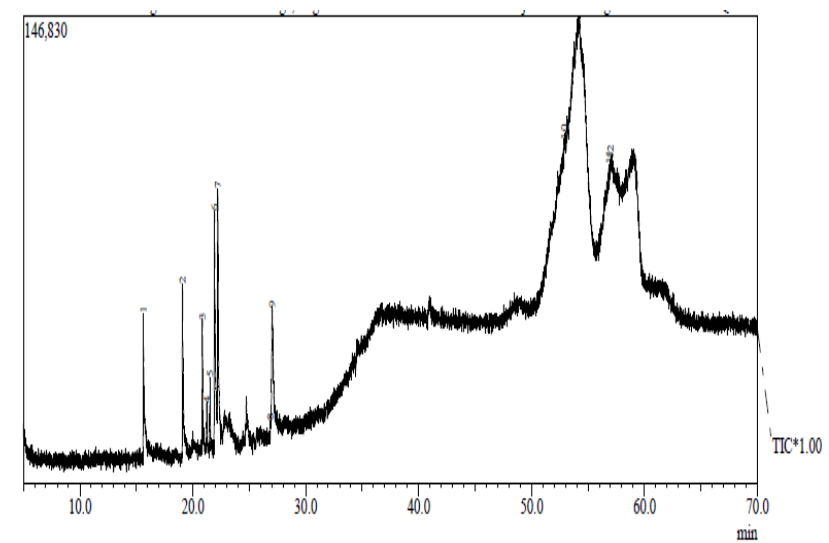

Gambar 1. Kromatografi Gas Metil Ester dari Biodiesel pada perbandingan mol reaktan $1: 35$, suhu $60{ }^{\circ} \mathrm{C}$ dan katalis $1,5 \%$ Berdasarkan data GC, maka berbagai jenis metil ester yang ada pada biodiesel dapat ditentukan. Kandungan metil ester pada biodiesel ditunjukkan pada Tabel 1 .
Tabel 1. Jenis Senyawa Metil Ester dalam Biodiesel

\begin{tabular}{lc}
\hline Nama senyawa & \% senyawa \\
\hline metil ester palmitate & 30,24 \\
metil ester nonadecanoate & 14,51 \\
3,7,11,15-tetramethyl & 11,50 \\
Methil Palmitoleat & 19,63 \\
Methil Acachidonate & 11,29 \\
\hline
\end{tabular}

Di dalam biodiesel kandungan metil ester paling besar adalah metil ester palmitate yang ditunjukkan oleh puncak nomor 10 dengan kandungan senyawa sebesar $30,24 \%$.

Sifat fisik dan kimia uji kualitas biodiesel Chlorella $S p$ dibandingkan dengan biodiesel standar SNI dan minyak solar dari minyak bumi disajikan pada tabel 2 di bawah ini.

Tabel 2 Perbandingan Karakteristik Biodiesel Hasil Percobaan dan Literatur Standar SNI

\begin{tabular}{lcl}
\hline Karakteristik & $\begin{array}{l}\text { Biodiesel } \\
\text { Chlorella }\end{array}$ & SNI \\
& & \\
\hline Massa jenis $(\mathrm{g} / \mathrm{ml}) 40^{\circ} \mathrm{C}$ & $0,840-0,848$ & $0,840-$ \\
Viskositas pd & $2,50-3,91$ & 0,890 \\
$40^{\circ} \mathrm{C}(\mathrm{cSt})$ & & $2,3-6,0$ \\
Angka Setana & $51,17-53,72$ & \\
Bil. Penyabunan & $2,677-3,542$ & Min 51 \\
mg KOH/kg & & $<5$ \\
Angka Asam mg KOH & $0,7-0.8$ & \\
/g & & Max 0,8 \\
\hline
\end{tabular}


Tabel 2 menunjukkan bahwa karakteristik fisik densitas, viskositas dan angka setana biodiesel pada hasil percobaan telah memenuhi karakteristik yang ditetapkan standart mutu biodiesel SNI dan minyak solar hasil minyak bumi. Untuk karakteristik kimia angka asam juga telah memenuhi standart.

\section{Analisa Biodiesel dari Mikroalga}

\section{Clorella sp}

\section{Analisa Angka Setana}

Parameter angka setana biodiesel dari chlorella $s p$ dapat dilihat pada gambar 2 .

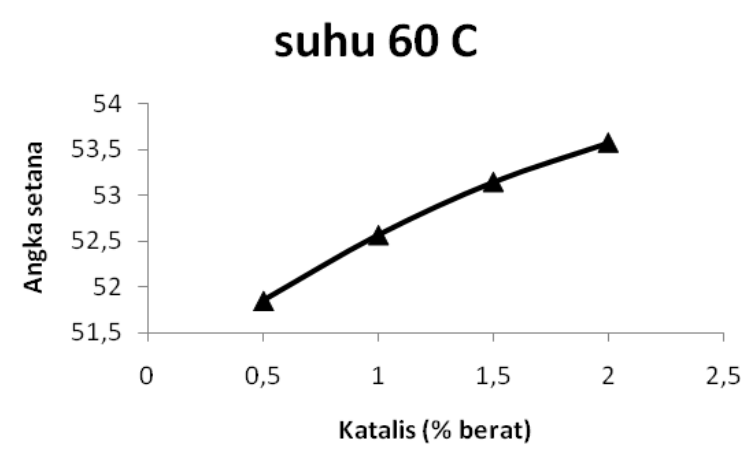

Gambar 2. Angka setana Biodiesel Chlorella sp dengan Variasi konsentrasi Katalis $\mathrm{KOH}$ pada suhu $60{ }^{\circ} \mathrm{C}$

Gambar 2 menunjukkan bahwa karakteristik angka setana biodiesel hasil percobaan telah memenuhi karakteristik yang ditetapkan standart mutu biodieel SNI dan minyak solar hasil minyak bumi. Angka setana biodiesel Chlorella sp adalah
51,17 - 53,58 lebih tinggi dari persyaratan SNI Biodiesel yaitu minimal 51.

\section{Analisa Angka Asam}

Parameter angka asam biodiesel dari chlorella sp dapat dilihat pada Tabel 3 Tabel 3 Angka Asam Biodiesel Chlorella $s p$ dengan Variasi Perbandingan reaktan pada suhu $60{ }^{0} \mathrm{C}$

\begin{tabular}{lllll}
\hline \multirow{2}{*}{$\begin{array}{l}\text { Perb } \\
\text { reaktan }\end{array}$} & \multicolumn{4}{c}{ Angka asam mg KOH /g } \\
\cline { 2 - 5 } & $\mathbf{0 , 5 \%}$ & $\mathbf{1 \%}$ & $\mathbf{1 , 5}$ & $\mathbf{2 \%}$ \\
& \multicolumn{4}{c}{$\%$} \\
\hline $1: 20$ & 0,72 & 0,74 & 0,78 & 0,72 \\
$1: 25$ & 0,78 & 0,76 & 0,80 & 0,76 \\
$1: 30$ & 0,80 & 0,74 & 0,76 & 0,79 \\
$1: 35$ & 0,79 & 0,78 & 0,79 & 0,80 \\
$1: 40$ & 0,76 & 0,80 & 0,78 & 0,76 \\
\hline
\end{tabular}

Tabel 3 menunjukkan bahwa karakteristik angka asam biodiesel hasil percobaan telah memenuhi syarat yang ditetapkan literatur. Nilai angka asam ini rata-rata hampir melebihi batas maksimal angka asam syarat mutu biodiesel menurut SNI-047182-2006, yaitu 0,8 mg KOH/ g minyak. Angka asam yang tinggi dapat menyebabkan endapan dalam sistem bakar dan juga merupakan indikator bahwa bahan bakar tersebut dapat berfungsi sebagai pelarut yang dapat mengakibatkan 
penurunan kualitas pada sistem bahan bakar (Markopala, 2010).

\section{Analisa Massa jenis}

Pengaruh konsentrasi katalis terhadap massa jenis disajikan pada Gambar 3. Pada Gambar.3 terlihat bahwa kenaikkan konsentrasi katalis dengan metode esterifikasi in-situ, berdampak pada kenaikkan massa jenis.

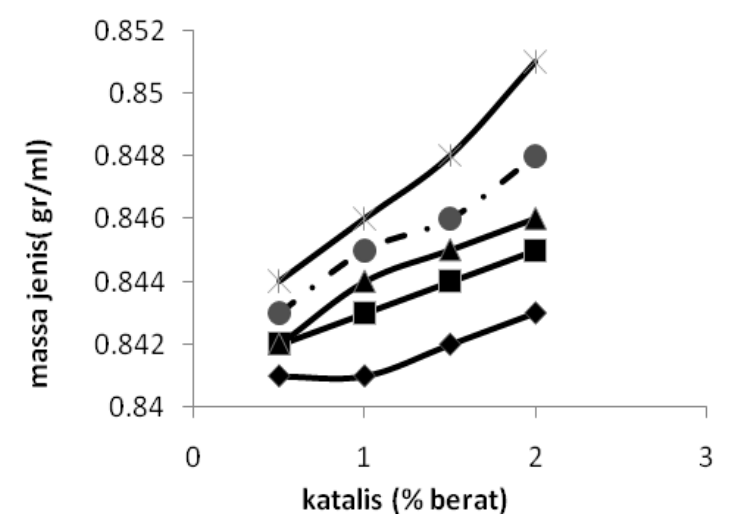

Gambar 3. Pengaruh kadar katalis pada bergai perbandingan reaktan terhadap massa jenis biodiesel

Menurut Peterson (2001), penggunaan katalis basa yang berlebih akan menyebabkan reaksi penyabunan. Hal ini memungkinkan adanya zat pengotor yang menyebabkan massa jenis biodiesel menjadi lebih besar.

\section{AnalisaViskositas}

Gambar 4. menyajikan Pengaruh konsentrasi katalis terhadap viskositas.

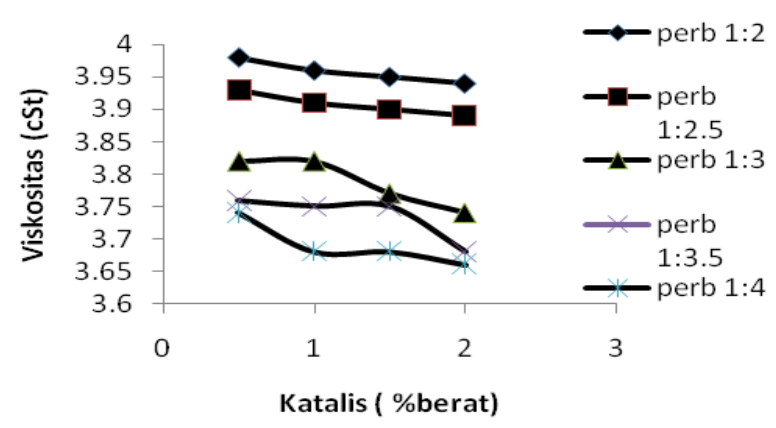

Gambar 4. Pengaruh katalis pada berbagai perbandingan mol reaktan terhadap viskositas biodiesel

Gambar 4 menyajikan pengaruh kenaikkan konsentrasi katalis terhadap viskositas. Semakin tinggi konsentrasi katalis, viskositasnya cenderung menurun. Karena semakin banyak persen katalis yang diberikan akan semakin cepat pula terpecahnya trigliserida menjadi tiga ester asam lemak yang akan menurunkan viskositas 5-10 persen (Prihandana, 2006).

Dari gambar 4. viskositas kinematik biodiesel dari masing-masing sampel telah sesuai dengan syarat mutu biodiesel menurut SNI-04-7182-2006, yaitu antara 2,3-6,0 cst. Viskositas yang terlalu tinggi dapat memberatkan beban pompa dan menyebabkan pengkabutan yang kurang baik (Soerawidjaja,2003).

\section{PengaruhPerbandingan}

reaktan terhadap Konversi Reaksi

Pengaruh Perbandingan Metanol terhadap Konversi Reaksi disajikan pada 
gambar 5. Pada gambar 5 terlihat bahwa kenaikan perbandingan reaktan berdampak pada kenaikan konversi pada pembuatan biodiesel.

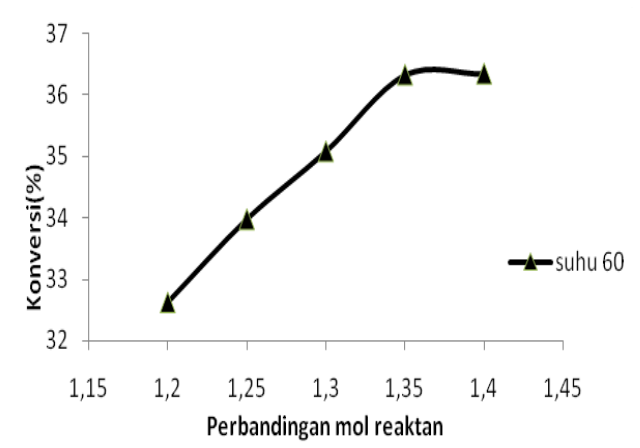

Gambar 5. Pengaruh Perbandingan mol reaktan pada suhu $60{ }^{\circ} \mathrm{C}$ terhadap konversi biodiesel

Dari gambar 5 menunjukkan bahwa konversi tertinggi didapatkan pada perbandingan reaktan 1:40. Pada perbandingan reaktan menunjukkan semakin tinggi perbandingan reaktan akan diperoleh konversi yang semakin besar untuk suhu yang sama. Hal ini dikarenakan pemakaian salah satu reaktan yang berlebih akan memperbesar kemungkinan tumbukan antara molekul zat yang bereaksi sehingga kecepatan reaksinya bertambah besar. Rasio molar metanol 1:40 digunakan untuk proses transesterifikasi oleh (Freedman $d k k$, 1986).

\section{Kesimpulan}

Dari analisa GC-MS telah terbentuk biodiesel dengan kandungan utama berupa metil ester metil palmitat sebesar $30,24 \%$. Biodiesel dari mikroalga Chlorella Sp dengan proses esterifikasi in-situ telah memenuhi standart mutu biodiesel SNI dengan konversi yang diperoleh sebesar $36,34 \%$.

\section{Daftar Pustaka}

Chisti, Y. (2007). "Biodiesel from microalgae. Biotechnol”. Adv. 25, 294306

Freedman, B., Pryde.E.H., Mounts. T.L.(1984). " Variables Affecting the Yields of Fatty Esters from Transesterfied Vegetable Oils".

Knothe G., Christopher A. S., and. Ryan T. W. (2006), "Exhaust Emissions of Biodiesel, Petrodiesel Neat Methyl Esters, and Alkanes in a New Technology Engine". Energy \& Fuels. 20: 403-408.

Markopala, P. (2010). “ Studi Efektivitas Transesterifikasi In-Situ Pada Ampas Kelapa Untuk Produksi Biodiesel". Thesis . ITB.

Peterson, C. L, J. C. Thomson, J. S. Taberski, D.L. Reece, G. Fleischman, 1999. LongRange On-Road Test With Twenty-Percent Rapeseed BiodieseL Applied Eng. In Agric. 15 (2):91-101.

Prihandana, Rama dan Hendroko, Roy, 2006. Energi Hijau 'Pilihan Bijak Menuju 
Negeri Mandiri Energi', PT Agromedia

Pustaka, Jakarta.

Riza, H. (2009). “ Sintesis Biodiesel Dari

Minyak Mikroalga Nannochloropsis Sp

Melalui Transesterifikasi Menggunakan

Katalis Basa". Proc. Seminar Nasional

F.MIPA. Semarang : Undip.

Soerawidjaja, Tatang H. (2006). "Fondasi-

fondasi Ilmiah dan Keteknikan dari Teknologi Pembuatan Biodiesel". Seminar Nasional Biodiesel Sebagai Alternatif Energi Masa Depan, Yogyakarta: Universitas Gadjah Mada.

Sri Hartini. (2010). "Uji Kelayaan Mutu Biodiesel hasil Ekstraksi Mikroalga Scenedesmus". Jurnal Nature indonesia.8 : 118-121

Suhada, Hendrata.(2001). "Fuel Cell Sebagai Penghasil Energi Abad 21". Jurnal Teknik Mesin. 2: $92-100$.

Vashista, B. R. (1979). "Botany for Degree Student”. New Delhi : Chand and Company $\mathrm{Lt}$ 
